\title{
"If They Notice I'm Mexican": Narratives of Perceived Discrimination from Individuals Who Crossed the U.S.-Mexico Border at Ports of Entry
}

\author{
Alexander H. Updegrove ${ }^{a}$, Joshua T. Shadwick ${ }^{a}$, Eryn Nicole O'Neala, and Alex R. Piquero ${ }^{b}$ \\ aSam Houston State University, Huntsville, TX, USA; ' University of Texas at Dallas, Richardson, TX, USA
}

\begin{abstract}
Understanding individuals' encounters with Customs and Border Protection (CBP), the largest law enforcement agency in the United States, is an important theoretical and policy-relevant issue. Travelers entering the U.S. through ports of entry may generalize their experiences with border officials to local law enforcement, and thus, negative experiences at ports of entry may reduce travelers' willingness to cooperate with police and report victimization. Existing studies, however, have primarily examined unauthorized border crossings rather than travelers' port of entry experiences. This study uses grounded theory and qualitative data to explore the perceptions and experiences of 191 young adults who discussed how individuals are treated when crossing the U.S.-Mexico border at land ports of entry. Findings show that participants reported perceptions and experiences of discrimination based on physical appearances, language differences, and nationality. Participants also described border officials engaging in routine law enforcement behaviors, including poor policing practices.
\end{abstract}

\section{ARTICLE HISTORY}

Received 12 July 2018

Accepted 21 October 2018

\section{Introduction}

In the post 9/11 landscape, anti-migrant sentiments have grown increasingly hostile among segments of the United States (U.S.) government and population (Dear 2013), especially under the current presidential administration. Much of this hostility has targeted Mexico, portraying the country as responsible for a myriad of problems the U.S. faces on its domestic front, including crime and drug use, and the closing of manufacturing plants in the Rust Belt. When Donald Trump first announced his presidential bid, he declared:

When Mexico sends its people, they're not sending their best. They're not sending you. They're sending people that have lots of problems, and they're bringing those problems with us. They're bringing drugs. They're bringing crime. They're rapists. And some, I assume, are good people (Hee Lee 2015: para. 1).

From the campaign trail, Trump routinely promised to build "a big, fat, beautiful wall" along the U.S.-Mexico border at Mexico's expense (Finnegan 2016: para. 6). After his election, Trump requested $\$ 18$ billion to fund the proposed border wall over the next decade (Gambino 2018). Trump also placed approximately 800,000 people at risk for deportation, as their protected status under the Deferred Action for Childhood Arrivals (DACA) program will expire over the next couple of years (Robbins and Dickerson 2018). Under the orders of U.S. Attorney General Jeff Sessions, the Trump Administration manufactured the separation of children from parents seeking asylum at the U.S.-Mexico border (Domonoske and Gonzales 2018). Most recently, Trump shut a quarter of the federal government down for 35 days in a failed attempt to secure $\$ 5.7$ billion to build his wall (Collins, Fritze, \& Jackson, 2019). This was the longest shutdown in U.S. history. 
Many consider Trump's rhetoric and policies to mischaracterize the reality of the U.S.-Mexico border (Heyman 2013). Others, however, have welcomed the increased marginalization of migrants under the new administration. The current director of Immigration and Customs Enforcement (ICE), for example, thanked Trump for having "taken the handcuffs off of law enforcement" (Bedard 2017: para. 1). The perception that Trump has authorized migrant-related law enforcement to operate without oversight or accountability is concerning given the documented abuses some U.S. Customs and Border Protection (CBP) officers have perpetrated (ACLU-New Mexico 2015). Although CBP is the largest law enforcement agency in the U.S., with 59,221 employees in fiscal year 2016 (U.S. Customs and Border Protection 2017a), little is known about the agency's dayto-day interactions with U.S.-Mexico border- crossers. This is because much of the existing literature focuses on unauthorized border crossings rather than authorized border crossings at ports of entry (De Leon, Gokee, and Schubert, 2015; Heyman 2012). Some evidence suggests that this oversight may have inadvertently fostered an environment conducive to human rights abuses at ports of entry (ACLU-New Mexico 2015; ACLU-Texas 2016).

Although policymakers such as Trump have justified changing border policing practices to better prevent unauthorized migrants from entering the U.S., there is no reason to assume that migrants are the only individuals who may be negatively impacted by port-of-entry policing practices. ${ }^{1}$ Indeed, border officials may view the current climate toward migrants as a license to treat port-ofentry travelers as they please without consequence. This possibility is worth investigating given that a similar organization, the Transportation Security Administration (TSA), was granted the discretion and authority to inspect airport travelers with virtually no oversight after the September 11, 2001 terrorist attacks (Brill 2016). Harrington (2014), a former TSA employee at Chicago's O'Hare airport, and other insiders have provided detailed accounts of the abuses TSA officers perpetrated in the name of preventing terrorism. Thus, it is possible that border officials may engage in similar abuses of power toward port-of-entry travelers in the name of preventing unauthorized migrants from entering the country. For this reason, the present study broadly focuses on the population of individuals who cross the U.S.-Mexico border at ports of entry rather than just the migrant subpopulation.

When discussing the U.S.-Mexico border, it is important to note that the majority of individuals who enter the U.S. travel through land ports of entry rather than cross between ports. In fiscal year 2016, the U.S. Border Patrol apprehended 404,870 unauthorized migrants trying to enter the U.S. along the U.S.-Mexico border (Department of Homeland Security 2016). ${ }^{2}$ In contrast, U.S.Mexico land ports of entry admitted an average of 688,757 travelers and 282,350 private vehicles each day during fiscal year 2016 (U.S. Customs and Border Protection 2017a). ${ }^{3}$ The number of individuals entering the U.S. through U.S.-Mexico land ports of entry has also grown in recent years,

\footnotetext{
${ }^{1}$ Police departments across the country, for example, first started using Special Weapons And Tactics (SWAT) teams in the 1960s and 1970s specifically for hostage and riot situations (Kraska and Kappeler 1997). By the mid-1990s, however, SWAT teams were being used primarily for drug raids (Kraska and Kappeler 1997). In the 2000s, some police departments regularly authorized SWAT teams to participate in situations where they were not necessary (e.g., serving arrest warrants with no anticipated risks to law enforcement; Culosi 2014). Although SWAT teams were not originally intended to serve arrest warrants that posed a minimal risk to law enforcement, their purpose nevertheless evolved over time. As a result, SWAT teams have accidentally killed individuals such as Salvatore J. Culosi Jr. (Jackman 2011). The same principle applies to port-of-entry policing practices. Even if the implementation of port of entry practices is considered justifiable on the basis of preventing unauthorized migrants from entering the U.S., there is no guarantee that these practices will not also have a spillover effect on non-migrant port-of-entry travelers.

${ }^{2}$ This figure reflects only those migrants Border Patrol apprehended and does not include those who crossed successfully without being detected. This figure also does not include contact with Border Patrol or other law enforcement that did not result in apprehension.

${ }^{3}$ These figures include individuals who legally cross the U.S.-Mexico border at ports of entry for a whole host of different reasons. Thus, it would be inaccurate to characterize everyone who crosses the U.S.-Mexico border at ports of entry as a migrant, Indeed, we do not cite these figures here to support such a contention. Instead, we cite these figures to demonstrate that U.S.-Mexico ports of entry process a high volume of traffic on a daily basis, thereby justifying the need to study how these individuals (whoever they may be, and whatever their reason for crossing the U.S.-Mexico border at a port of entry) are treated by border officials.
} 
although these numbers have yet to return to pre-9/11 levels. In 2017, 42.3 million pedestrians entered the U.S. through U.S.-Mexico land ports of entry, up from 39.9 million in 2010 (Bureau of Transportation Statistics n.d.). Similarly, in 2017, 143.6 million personal vehicle passengers drove 77.9 million personal vehicles into the U.S. through U.S.-Mexico land ports of entry, up from 125.7 million passengers in 64.0 million vehicles in 2010. These numbers support broadening research efforts to include the study of border-crossing experiences and policing practices at U.S.Mexico ports of entry.

Understanding U.S.-Mexico border travelers' perceptions and experiences of their interactions with CBP at ports of entry is important for several reasons. First, despite CBP's status as the largest law enforcement agency in the U.S. (U.S. Customs and Border Protection 2017a), scholars have rarely studied travelers' perceptions and experiences of their interactions with CBP. Second, the limited research on CBP's treatment of border-crossers - especially the work of Sarabia (2015), Chavez (2008), and Rosas (2006) - focuses almost exclusively on how CBP treats unauthorized immigrants, rather than how CBP treats U.S.-Mexico port-of-entry travelers (Heyman 2012). The total number of individuals who entered the U.S. through U.S.-Mexico ports of entry during the average day in fiscal year 2016, however, outnumbered the total number of unauthorized individuals apprehended while entering the U.S. during the entire 2016 fiscal year (Department of Homeland Security 2016; U.S. Customs and Border Protection 2017a). The sheer volume of traffic processed at U.S.-Mexico ports of entry, therefore, suggests that research is needed in this area. Third, real or perceived shifts in the political climate may influence how the border is enforced, resulting in increases or decreases to the number and type of problematic policing practices CBP officers engage in. The previously discussed comment from the current ICE director suggests that this may be the case (Bedard 2017: para. 1).

The contributions mentioned above are particularly salient because CBP officers may be the first or only U.S. law enforcement contact to which many port-of-entry travelers are exposed. Consequently, the quality of this interaction may shape travelers' later attitudes toward local police and government officials in addition to influencing their willingness to cooperate with police or report victimization experiences (Seghetti 2016). This resonates well with recent scholarship that has focused on the process of legal socialization and the importance of procedurally-just contacts with law enforcement to help shape and support the legitimacy of the law (Tyler 1990; Tyler and Trinkner 2018). Prior research has shown that positive contacts with law enforcement and other justice system personnel are related to legitimacy which, in turn, protects against antisocial behavior (see Fagan and Piquero 2007; Piquero et al. 2005; Tyler 2003). For these reasons, it is imperative that CBP officers provide the highest quality services possible by upholding professed U.S. values like equality, fairness, justice, and respect for human rights (ACLU-Texas 2016; Revitalize Not Militarize n.d.). ${ }^{4}$ The present study examines narratives from 191 young adults who traveled through U.S.-Mexico ports of entry in order to understand their perceptions and experiences of crossing the border, and how the apparent racialized treatment travelers receive may vary based on personal or situational characteristics (see Chacón and Coutin 2018; Ortiz and Telles 2012).

\section{U.S. customs and border protection}

The U.S. Customs and Border Protection (CBP) was established on March 1, 2003, under the Department of Homeland Security (DHS) (U.S. Customs and Border Protection 2017b). In creating the CBP, several previously independent agencies and programs merged to form a single, centralized organization responsible for policing the border (U.S. Customs and Border Protection 2017c). CBP officers are responsible for enforcing agricultural laws, customs, and

\footnotetext{
${ }^{4}$ We use the term "professed" here because Coates (2015), Glaude (2016), and others have presented compelling arguments that suggest these ideals are less consistently applied to interactions involving people of color in the United States - and likely were never intended to be applied to such interactions in the first place.
} 
immigration; preventing human, drug, and contraband trafficking; and preventing terrorists from entering the U.S. (U.S. Customs and Border Protection 2017d). CBP is estimated to have more than 60,000 employees (Cruz and Payan 2017), and operates on an annual budget that exceeds $\$ 15$ billion (U.S. Customs and Border Patrol 2017c). Consequently, CBP is the largest law enforcement agency in the U.S. (Cruz and Payan 2017). The most recognizable CBP offices include Air and Marine Operations, the U.S. Border Patrol, and the Office of Field Operations (U.S. Customs and Border Protection 2017a).

Although the U.S. Border Patrol is prominently featured in news coverage and receives the most political attention, the Office of Field Operations (OFO) accounts for the greatest number of CBP employees. OFO operates on a yearly budget of $\$ 5.2$ billion, and employs more than 28,000 individuals (U.S. Customs and Border Protection 2017d). The principal objective of OFO is to maintain safety along the U.S. border by monitoring and inspecting individuals, vehicles, and goods that pass through U.S. ports of entry (U.S. Customs and Border Protection 2017c). Ports of entry are "locations where people legally enter or leave the country by land, air, or sea" (The Pew Charitable Trusts 2015:6).

Pedestrians and personal vehicles may cross the U.S.-Mexico border at any of 26 land ports of entry. Twelve ports are located in Texas, two are in New Mexico, and six are in Arizona and California each. According to the Bureau of Transportation Statistics (n.d.), 42.3 million pedestrians entered the U.S. through these 26 land ports in 2017. That same year, 77.9 million personal vehicles brought 143.6 million people to the U.S. through these ports, and 171,896 buses transported 1.7 million people. Because the U.S. Border Patrol receives a disproportionate amount of CBP's resources, OFO is chronically short-staffed, and "vast lines of overheating cars and sweltering pedestrians" characterize many U.S.-Mexico ports of entry (Heyman 2012:267; Meyer, Isacson, and Scorpio, 2016).

\section{Entering the U.S. at ports of entry}

For most individuals, the process of entering the U.S. through land ports of entry begins by applying for a visa at a U.S. Consulate or Embassy in their home country (Seghetti 2016). Following this, individuals present themselves at a port of entry for primary inspection (also known as preclearance). During primary inspection, OFO officers scrutinize individuals' travel documents and ask clarifying questions to determine their eligibility for entering the U.S. (Seghetti 2016). The names of individuals are also checked in a federal database to determine whether they have been previously flagged for overstaying a visa, entering the county without authorization, or committing a crime. If OFO officers feel it is necessary, they may search persons, vehicles, or possessions without establishing reasonable suspicion or obtaining a warrant (19 C.F.R. 162.6). Primary inspection has three potential outcomes: (1) individuals are admitted into the U.S.; (2) they are denied entry; or (3) they are referred to secondary inspection.

Secondary inspection consists of pulling pedestrians or personal vehicle passengers aside for additional questioning (Seghetti 2016). In many cases, individuals sent to secondary inspection are placed in holding cells similar to police interrogation rooms and subjected to intense periods of questioning, often without explanation (Heyman 2001). OFO officers typically divert individuals into secondary inspection for appearing suspicious or being flagged in the federal database (Seghetti 2016). The Random Compliance Examination (COMPEX) program also subjects some individuals to secondary inspection by randomly alternating between green and red traffic lights, with red lights indicating that an individual has been chosen for secondary inspection (Ortiz and Contreras 2011; Seghetti 2016). In fiscal year 2013, the latest year for which data exists, $12.3 \%$ of individuals seeking to enter the U.S. through a land port were diverted into secondary inspection (Seghetti 2016). Although OFO officers can deny travelers admission into the U.S. for "any reason," the majority of individuals are ultimately admitted, with only 5 out of every 10,000 travelers turned away (Seghetti 2016:11).

Understaffing and long wait times at ports of entry create an environment where OFO officers may be more likely to use cognitive heuristics rooted in racial and national stereotypes 
to assess individuals' eligibility for entry (Chavez 2011; Heyman 2009). This possibility is amplified by requiring OFO officers to police individuals' intentions (e.g., determine if they intend to overstay their visa or work in the U.S.). Policing ports of entry is further complicated by the fact that drug smugglers and individuals attempting to reenter the U.S. after a prior deportation are frequently indistinguishable from other travelers. This is because drug smugglers do not appear visually or behaviorally distinct from other travelers, and previous deportees may use stolen or forged traveler documents to pass federal database checks. Short-staffed OFO officers, therefore, are tasked with accurately isolating a small group of deviant individuals from the physically and behaviorally identical law-abiding multitudes, all under pressure to keep traffic steadily moving (Heyman 2001). The stress of this mission, combined with personnel shortages, creates a logistical challenge that increases the likelihood that some OFO officers may act on explicit or implicit biases. The types of legal decision-making OFO officers engage in is vulnerable to the same biases that characterize general information processing, such as focusing on information consistent with pre-existing beliefs and ignoring evidence to the contrary (McEwan 2003).

\section{Abuses of power at U.S. ports of entry}

Some border officials display explicit or implicit biases against "Mexican-looking" travelers because they think individuals who fit this profile account for a disproportionate amount of border violations (ACLU-New Mexico 2015; ACLU-Texas 2016; Heyman 2009:385; Saldivar 2017). Because U.S.-born Latinxs, Spanish speakers, and Native Americans all share some readily identifiable characteristic (e.g., language, accent, or skin tone) with Mexican nationals at first glance, they are often treated as "guilty by association" (Amnesty International 2012; Levario 2012:122). Thus, human rights violations along the U.S.-Mexico border tend to be disproportionately concentrated among dark-skinned travelers with prominent Latinx features, regardless of their U.S. residency or citizenship status (ACLU-New Mexico 2015; ACLU-Texas 2016). Research by Ortiz and Telles (2012) supports this assertion, as the authors reported that darker-skinned Mexican Americans disclosed a greater number of discrimination experiences than lighter-skinned Mexican Americans. The authors also found that, in general, darker-skinned men self-reported more experiences of discrimination than lighter-skinned men.

The Texas and New Mexico American Civil Liberties Unions have documented numerous abuses perpetrated against border-crossers at U.S.-Mexico ports of entry (ACLU-New Mexico 2015; ACLUTexas 2016; Saldivar 2017). Trinidad Muraira de Castro, for example, was aggressively interrogated for 10 hours alongside her two daughters and one-month-old granddaughter. During interrogation, Trinidad falsely confessed that her daughters had been born outside the U.S. and were not U.S. citizens. OFO officers used this coerced "confession" to bar Trinidad's daughters from entering the U.S. (American Civil Liberties Union 2012). Similar tactics have been used to turn others away at U.S.-Mexico ports of entry, including the theft and destruction of legal documents authorizing entry to the U.S. (American Civil Liberties Union 2012; Chavez 2011; Huspek, Martinez, and Jimenez 1998).

Some travelers have also been subjected to physical violence at U.S.-Mexico ports of entry (Sabo et al. 2014). In one case, an OFO officer repeatedly asked Trosky Vasquez the same series of questions, which he voluntarily answered. As the OFO officer continued asking the same questions, Trosky protested that he had already answered all of the officer's questions. At this point, the OFO officer ordered Trosky out of the car. When Trosky asked for an explanation, the officer violently handcuffed him and rushed him into secondary inspection, where he was repeatedly physically and verbally assaulted (American Civil Liberties Union 2012). A second traveler, Cruz Marcelino Velazquez Acevedo, suffered cardiac arrest when an OFO officer knowingly ordered Cruz to drink liquid methamphetamine that Cruz claimed was apple juice. Cruz died after his body temperature reached 105 degrees and his heartbeat climbed to 220 beats-per-minute (Phillips 2017). 
Other travelers have experienced severely intrusive body searches stemming from port-of-entryrelated incidents. In one case, OFO officers transported Jane Doe, a middle-aged U.S. citizen, from a U.S.-Mexico port of entry to a local U.S. hospital, where medical staff voluntarily and consistently violated Doe's body in search of drugs. At no point did OFO officers obtain any evidence to support their suspicion. A thorough account of this incident was described in an ensuing lawsuit (Jane Doe v. The El Paso County Hospital District 2013:2):

First, government agents stripped searched Ms. Doe and made a visual and manual inspection of her genitals and anus. Finding nothing, Defendants next subjected her to an observed bowel movement. When that procedure yielded no evidence of drugs, Defendants X-rayed Ms. Doe. Having found nothing, Defendants next shackled Ms. Doe to an examining table and inserted a speculum into her vagina, performed a rectal exam on her, and conducted a bimanual cavity search of her vagina. Still not satisfied, Defendants subjected Ms. Doe to a CT scan and again found no evidence of drugs.

Medical staff violated Doe's privacy by allowing OFO officers to observe the entire incident from inside the room, and by leaving the door to the hallway open so that individuals passing by could look in. In the following weeks, the hospital billed Doe for more than $\$ 5,000$ to cover the costs of the involuntary medical procedures. At least a couple of other women have experienced similar treatment from OFO officers and hospital staff (Bustillos v. El Paso County Hospital District 2016; Cervantes v. United States of America 2016). These examples suggest that some border-crossers face discrimination and/or human rights violations at U.S.-Mexico ports of entry. ${ }^{5}$

\section{Current study}

To date, scholars have largely focused on unauthorized migrant experiences in the U.S. and neglected border-crossing experiences at U.S.-Mexico ports of entry (De Leon, Gokee, and Schubert, 2015; Heyman 2012). This oversight may inadvertently foster an environment conducive to human rights abuses at ports of entry. As national discourse and scholarship has not devoted much attention to examining how border officials treat U.S.-Mexico port-of-entry-travelers, researchers need to document the everyday realities travelers encounter at ports of entry in order to better understand the shape and scope of the problem, as well as encourage transparency and accountability (Huspek, Martinez, and Jimenez, 1998; Saldivar 2017). Studies of this nature are timely in the present political climate, and especially warranted given that the number of pedestrians and personal vehicle passengers entering the U.S. through U.S.-Mexico land ports of entry has increased by 2.4 million and 17.9 million, respectively, from 2010 to 2017 (Bureau of Transportation Statistics n.d.). Developing an understanding of these interactions and experiences is also important from a theoretical and policy perspective - the former regarding the legal socialization process surrounding law and social control systems, and the latter regarding legal enforcement procedures. The present study explores the perceptions and experiences of young adults who discussed how border officials treat U.S.-Mexico land port-of-entry-travelers.

\section{Data \& methods}

Data for the current study are derived from a larger project designed to examine whether individuals who were more oriented toward U.S. culture expressed greater death penalty support than individuals who were more oriented toward Mexican culture (Updegrove, 2018). A random sample of college students enrolled in two public Texas universities, one of which resides along the U.S.-

\footnotetext{
${ }^{5}$ Although we highlight these specific instances of abuse, we do not mean to suggest that they are routine occurrences at U.S.Mexico ports of entry - especially given the high volume of traffic that is processed daily at these ports. Instead, we present these cases of abuse to demonstrate that at least a few OFO officers have abused their authority on at least one occasion, and therefore the topic appears to warrant further exploration. Without a public database containing the number of reported abuses experienced at port-of-entry border crossings, we cannot speculate on how rare or frequent these events may (or may not) be.
} 
Mexico border, was obtained for this project during fall 2017. Courses were selected according to a random number generator, and surveys were administered both in class and online. Students absent from class on the day the survey was administered were sent a follow-up email containing the online survey link. The resulting sample for this project was representative of both universities' enrollment bodies. ${ }^{6}$

Students were asked whether they had ever crossed the U.S.-Mexico border at a border checkpoint. Of the 1,609 students who responded to this item, 972 indicated that they had crossed the U.S.-Mexico border at least once in their lifetime. These 972 students were asked four open-ended questions:

(1) When crossing the U.S.-Mexico border at a border checkpoint, have you ever been treated differently than those around you? (If yes, please describe your experience).

(2) When crossing the U.S.-Mexico border at a border checkpoint, have you ever witnessed someone around you being treated differently than everyone else? (If yes, please describe the experience).

(3) When crossing the U.S.-Mexico border at a border checkpoint, have you or someone around you ever been harassed or mistreated by an individual in authority? (If yes, please describe the experience).

(4) When crossing the U.S.-Mexico border at a border checkpoint, have you or someone around you been treated differently by an individual in authority based on race, ethnicity, or country of origin? (If yes, please describe the experience).

Of the 972 students who had crossed the U.S.-Mexico border at least once in their life, 191 provided a response to at least one of the four open-ended questions (11.9\% of the original sample of 1,609 participants; $19.7 \%$ of individuals who had crossed the U.S.-Mexico border at least once in their life). Compared to the sample who had crossed the U.S.-Mexico border at least once in their lifetime but declined to give a qualitative answer $(n=781)$, participants who gave a qualitative response $(n=191)$ were significantly older (by a year), less likely to be non-Latinx White, and more likely to cross the U.S.-Mexico border at least once a week. No gender differences existed among participants who gave a qualitative response and those who did not. Unsurprisingly, participants who attended the university located along the U.S.-Mexico border were more likely to provide a qualitative response than participants who attended the university located further away from the border.

Of the 191 participants in the final sample, 108 (56.5\%) answered the first question, $112(58.6 \%)$ answered the second question, 74 (38.7\%) answered the third question, and 81 (42.4\%) answered the fourth question. The average participant responded to 1.96 of the four questions, with participants more likely to have responded to the first two questions. Fifty-nine percent of participants were female; the remaining $41 \%$ self-reported as male. Eighty-eight percent of the sample was Latinx, with $7 \%$ non-Latinx White, $1 \%$ non-Latinx Black, and 4\% non-Latinx of another race. Regarding age, 79\% of the sample was 24 years old or younger. Finally, $30 \%$ of the sample reported being in a committed relationship.

\footnotetext{
${ }^{6}$ According to the Integrated Postsecondary Education Data System (n.d.), University 1 's enrollment body was $53 \%$ female and $47 \%$ male during fall 2016, the latest year for which data exists. $83 \%$ of those enrolled were Latinx, $6 \%$ were non-Latinx White, $2 \%$ were non-Latinx Black, and $9 \%$ were non-Latinxs of another race. $76 \%$ were age 24 or younger. In the present study, the subsample of participants from University $1(n=840)$ was $58 \%$ female and $42 \%$ male. $84 \%$ were Latinx, $7 \%$ were non-Latinx White, $3 \%$ were non-Latinx Black, and $6 \%$ were non-Latinxs of another race. $82 \%$ were age 24 or younger. Thus, the demographic composition of the responses received from University 1 appears to reflect the demographics of University 1's enrollment body from fall 2016. According to the Integrated Postsecondary Education Data System (n.d.), University 2's enrollment body was $62 \%$ female and $38 \%$ male during fall $2016.22 \%$ of those enrolled were Latinx, $51 \%$ were non-Latinx White, $18 \%$ were non-Latinx Black, and $9 \%$ were non-Latinxs of another race. $84 \%$ were age 24 or younger. In the present study, the subsample of participants from University $2(n=769)$ was $65 \%$ female and $34 \%$ male. $34 \%$ were Latinx, $41 \%$ were nonLatinx White, $16 \%$ were non-Latinx Black, and $9 \%$ were non-Latinxs of another race. $94 \%$ were age 24 or younger. Similar to University 1, the demographic composition of the responses received from University 2 appears to reflect the demographics of University 2's enrollment body from fall 2016, with the caveat that individuals from University 2 in the sample were more likely to be Latinx and less likely to be non-Latinx White.
} 
Because the present study is qualitative in nature and relies on respondents' narratives about their border-crossing experiences, it is important to consider the sample size used. Qualitative researchers contend that saturation is often achieved at relatively low levels and generally requires no more than 60 participants (Bernard 2000; Charmaz 2014 ; Creswell 1998; Morse 1994). Specific to the analytic strategy used in this study (i.e., grounded theory, discussed in the section below), Morse (1994) recommends a sample size between 30 and 50 participants, Creswell (1998) recommends a range between 20-30, and Charmaz (2006) suggests that 25 participants is a satisfactory sample size. Because narratives from the present study emerge from 191 participants, the sample size is large enough to allow for identification, descriptive redundancy, and theoretical saturation.

\section{Data analysis}

Qualitative data from the question prompts discussed above are used to identify thematic narratives as they relate to differential treatment experiences of individuals crossing the U.S.-Mexico border at land ports of entry. To do so, the present study relies upon the systematic methods of Glaser and Strauss' (1967) grounded theory approach to qualitative analysis. A thorough examination of the data was undertaken in order to assign codes to phenomena and identify themes that repeatedly appeared. The lead author systematically read each participant's responses to the four open-ended questions while performing a line-by-line text analysis of the various answers. Analysis operated in an inductive framework; coding was substance derived and not resulting from preconceived notions or categories (Charmaz 2014). The initial text analysis yielded summaries of the main points contained in each response (Mayring 2014). Responses with similar main points were grouped together into initial categories. During early stages of the coding process, it was necessary to create additional initial categories to group similar main points together. Detailed notes were written during this process to ensure reliability and to assist in the next step, the constant comparison method (Glaser and Strauss 1967). Constant comparison involves determining whether codes and themes identified in one response apply across responses (Charmaz 2014). For example, as the coding process progressed, new categories were only added if the main point of a participant's response could not be subsumed under an already existing initial category. The constant comparison step - a feature of qualitative research that enhances both reliability and validity - is vital to the process because it assists in theory development during each step of analysis (Charmaz 2014; Morse et al. 2002). Categories were not mutually exclusive, and many responses met criteria for inclusion in multiple categories.

Given the objectives of this study, the emphasis in note-taking was on highlighting the experiences of individuals crossing the U.S.-Mexico border at land ports of entry. Using Glaser and Strauss' (1967) approach allows for the use of systematic strategies centered on the idea of theory development from research grounded in data, rather than deducing testable hypotheses from existing theories (Charmaz 2006; Clark 2005). As a result, the scope and focus of initial categories naturally evolved as more main points were added to each category. This resulted in some early themes being abandoned, other themes being revised, and still other themes being created midway through the initial coding process. Thus, after the entire set of responses had been coded through once, each response was coded a second time to ensure that it had been properly assigned codes according to the evolved, finalized categories. As a final step, categories that shared broad similarities with other categories were reorganized as subcategories under the umbrella head of more general, overarching themes. Overall, this methodology is well suited for the data in this study given the underdeveloped nature of port-of-entry border-crossing research.

\section{Results}

Five broad, overarching themes regarding differential treatment were identified in participants' perceptions and experiences of crossing the U.S.-Mexico border through land ports of entry. As Table 1 indicates, each theme contains several subcategories. The first major theme identified is discrimination 
Table 1. Major themes and subcategories for U.S.-Mexico port-of-entry travelers' perceptions and experiences of treatment by border officials $(\mathrm{N}=191)$.

\begin{tabular}{lrr}
\hline Theme & $\mathrm{N}$ & $\%$ \\
\hline Discrimination based on physical appearances/social/ascribed characteristics & $\mathbf{6 2}$ & $\mathbf{3 2 . 5} \%$ \\
Colorism & 39 & $20.4 \%$ \\
Mexican/Latinx features & 7 & $3.7 \%$ \\
Age & 4 & $2.1 \%$ \\
Possessions & 12 & $6.3 \%$ \\
Other appearance-based biases & 13 & $6.8 \%$ \\
Language-based discrimination & $\mathbf{2 6}$ & $\mathbf{1 3 . 6 \%}$ \\
English proficiency & 16 & $8.4 \%$ \\
Foreign accent/pronunciation & 7 & $3.7 \%$ \\
Other language-based biases & 5 & $2.6 \%$ \\
Nationality-based discrimination & $\mathbf{5 5}$ & $\mathbf{2 8 . 8} \%$ \\
Mexican versus American nationalities & 37 & $19.4 \%$ \\
ID documentation/legal status & 23 & $12.0 \%$ \\
Law enforcement behaviors & $\mathbf{6 3}$ & $\mathbf{3 3 . 0} \%$ \\
Heightened scrutiny/interrogation & 22 & $11.5 \%$ \\
Person/vehicle/possessions searched & 15 & $7.9 \%$ \\
Detained/arrested & 25 & $13.1 \%$ \\
Confronting illegal behavior & 8 & $4.2 \%$ \\
Militarization & 2 & $1.0 \%$ \\
Perceived Problematic behaviors & $\mathbf{7 2}$ & $\mathbf{3 7 . 7} \%$ \\
Rude behavior/harassment & 50 & $26.2 \%$ \\
Entitlement/lack of empathy & 13 & $6.8 \%$ \\
Theft/loss of property & 3 & $1.6 \%$ \\
Victimization & 11 & $5.8 \%$ \\
\hline
\end{tabular}

based on physical appearances or social/ascribed characteristics $(n=62)$. The second major theme identified is language-based discrimination $(n=26)$. The third major theme identified involves discrimination based on individuals' nationality $(n=55)$. The fourth major theme identified consists of common law enforcement behaviors perceived or experienced while crossing the border $(\mathrm{n}=63)$. Finally, the fifth major theme identified describes perceived problematic behaviors OFO officers engaged in that may constitute poor policing practices or, in a few instances, human rights violations $(n=72)$. Below, we describe the subcategories that fall under each of these broader overarching themes.

\section{Discrimination based on physical appearances/social-ascribed characteristics}

\section{Colorism}

Thirty-nine participants described perceived differential treatment from OFO officers based on the color of border-crossers' skin. This differential treatment resulted in individuals with lighter skin being processed efficiently with minimal delays, and individuals with darker skin being treated suspiciously and subjected to extended questioning. ${ }^{7}$ Juan, ${ }^{8}$ a 27 -year-old Latino, described the following experience: "Being a light skin Mexican-American man, I get mistaken for looking White. Other family members are considerably darker than I and often sometimes are not treated as well as myself." Another participant reported that, "The darker shade of brown [a border-crosser's skin is], the ruder the [OFO] officer behaves."

Ben, a 23-year-old White male, was able to pass through ports of entry quickly with minimal interactions when all of the passengers in his car were light-skinned, but had a different experience when transporting passengers of color. In his response, he stated, "Only if I have a passenger who is Black, Hispanic, or Asian will the [OFO] officer acknowledge the vehicle, as if they were solely looking for non-White passengers." A 53-year-old Latina described receiving better treatment from

\footnotetext{
${ }^{7} \mathrm{~A}$ related strand of research has examined the perceived stereotypicality of Black defendants and found that, to the extent that people perceive Black defendants to be more stereotypically Black, they are more likely to be sentenced to death in cases involving a White victim (Eberhardt et al. 2006).

${ }^{8}$ All names are pseudonyms used to protect participants' privacy.
} 
OFO officers because of her lighter skin: "If I cross alone, I have no problems. But when I used to cross with my ex-husband, who happens to look very Mexican (dark skin), we were always asked too many questions, and even had our car inspected."

Several participants described receiving better treatment from OFO officers when traveling with a light-skinned person. For example, Maria, an 18-year-old Latina, recounted lengthier interactions with OFO officers when her family traveled without her light-skinned stepfather: "My stepfather is White while I'm Hispanic; crossing without him takes longer for officers to let us go through. Crossing with him guarantees the officer to give us one look and let us cross." Thus, for many participants, possessing lighter skin yielded privileges not afforded to darker-skinned individuals. These privileges included being viewed less suspiciously, being treated with more respect, not having their legal status or documents questioned, being asked few (if any) questions, being less likely to be searched or sent to secondary inspection, and ultimately, passing through ports of entry quicker than their darker-skinned peers. As Maria's case demonstrates, even proximity to light-skinned individuals can ease the suspicion with which some OFO officers regard darker-skinned individuals.

\section{Mexican/Latinx features}

Similar to colorism, seven participants reported the perception that OFO officers profiled travelers who possessed prominent Mexican or Latinx physical features. According to these respondents, appearing Mexican or Latinx increased OFO officers' suspicions that border-crossers were transporting drugs or unauthorized to enter the United States. As Juanita, an 18-year-old Latina, put it, "Hispanics are always thought to be smuggling something in." OFO officers were also perceived to treat U.S. Latinx citizens as "guilty by association" for appearing indistinguishable from their Mexican national counterparts (Levario 2012:122): "The border patrols [OFO officers] are mean to those who look Mexican, even though they are U.S. citizens and they are crossing [the border] to go to school. They [OFO officers] are the worst."

Another participant noted OFO officers appeared to discriminate against "people with strong Hispanic physical characteristics.” This suggests that some OFO officers may hold explicit or implicit biases against individuals who appear more stereotypically Mexican or Latinx. Julio, a 34-year-old Latino, observed that, "Sometimes for simply having Hispanic features, you may be treated differently." The experiences of Paulina, a 53-year-old Latina, captures the apparently arbitrary nature of some OFO officers' discrimination: "They [OFO officers] usually treat me better because I look Anglo (I have fair skin and light color eyes), but if they notice I'm Mexican, their attitude changes in a negative way." Here, Paulina described OFO officers abruptly switching their behavioral scripts as soon as they noticed her Mexican features.

\section{Age}

Four participants perceived OFO officers to treat elderly individuals with greater suspicion. Responses suggest that some OFO officers may become frustrated with older border-crossers who cannot speak or understand English. Alternatively, some OFO officers may mistreat older bordercrossers because the language barrier reduces the likelihood that victims will report the abuse. Isabella, an 18-year-old Latina, observed that, "Being a young U.S. citizen and fluent in English, I seem to receive better treatment than elderly Mexican people who are non-English speakers." Other participants perceived the quality of interactions with OFO officers to vary based on "age group," with "elderly people" receiving lower quality interactions.

\section{Possessions}

Twelve participants described differential treatment based on the clothes travelers wore, how poor or wealthy they appeared, or the type of car they drove. Camila, a 22-year-old Latina, reported a history of harassment and unnecessary questioning whenever she crossed the border. She interpreted this pattern of behavior as: "[Me] being a young Hispanic female, driving alone - driving a vehicle I feel 
he [the OFO officer] determined I could not afford and therefore it had to be stolen or provided for illegal purposes."

In general, participants perceived that poor people were treated with contempt, and people who displayed wealth through possessions were profiled as drug smugglers who could only afford their possessions through a criminal lifestyle. Lucia, a 20-year-old Latina, felt as if "most Mexicans who clearly are of a lower social status are treated rudely most of the time." Another participant reported being "profiled for my attire and my vehicle." Javier, a 26-year-old Latino, noted that OFO officers "dislike that you have certain materialistic things such as a brand new car." However, participants also communicated that "people with raggedy cars got treated different," too. Thus, both meager and grandiose displays of wealth were perceived to correspond with poorer treatment from OFO officers.

In this context, Javier also highlighted the power that OFO officers hold to either grant or deny individuals entry to the U.S., stating "by the way they [border-crossers] dressed or they look, they were denied permits [to cross the border]." One participant observed OFO officers automatically send two men dressed in traditional Arabic clothing to secondary inspection. This suggest that some OFO officers may exhibit biases against Middle-Eastern travelers in addition to travelers who share features with negative Mexican stereotypes.

\section{Other appearance-based biases}

Thirteen participants mentioned other experiences where physical appearances appeared to play a role in how OFO officers treated border-crossers. Arianna, a 20-year-old Latina, highlighted how an individual's perceived gender can shape their interactions with OFO officers, stating, "if you don't have males with you, you are much more likely to be treated differently." Olivia, a 38-year-old Latina, told the following story: "I have literally been told by a customs agent [OFO officer] that 'girls who look like me tend to be drug smugglers.' I get pulled over by customs almost every time I cross back into the U.S." Another individual discussed being treated suspiciously "because of his tattoos," which may indicate that some OFO officers view tattoos as a sign of drug cartel or gang involvement. Roberto, a 19-year-old Latino, recounted an experience where OFO officers put his health issue on display for their personal amusement: "One [OFO] officer started to make fun of my heart pulse, because I have a pretty fast pulse - most of the time my hands are shaking. So when I told him about my health issue, he started to laugh and called other officers to come and see."

\section{Language-based discrimination}

\section{English proficiency}

Sixteen participants reported that some OFO officers expected border-crossers to speak English during their interactions. Rosa, a 21-year-old Latina, appeared to express resentment at the fact that English was assumed to be the default language for interactions with OFO officers, saying, "They expect Mexican people to speak English. If that's the case, why can't they learn Spanish too????" Another participant observed that, "officers are very rude and disrespectful to people that do not speak English." This resulted in some non-English speakers experiencing lengthier interactions with OFO officers: "The customs agents [OFO officers] tend to be more interrogative of my parents who do not speak English than with my sisters and I, who are fluent English speakers." Micaela, an 18year-old Latina, similarly reported, "My parents are always treated different just because of their lack of the English vocabulary."

Along the same lines, participants perceived OFO officers to view English-speakers with less suspicion and often permit them to cross the border with minimal interruptions. As one participant stated, "My fluent English has led me to pass through [the border] fairly easily." In some instances, speaking fluent English appears to signal in-group membership (as a U.S. citizen) and allay OFO officers' suspicions: 
I don't feel like I have been treated differently, but my experience is unique to me since I speak "perfect" English despite my appearance. When I come up you can see the prejudice in their [OFO officers'] eyes because of my brown skin, but once I speak in English they treat me fairly well. I have met many people and my own mother [who] have been treated unjustly because either they don't speak English or they speak it with difficulty.

On the other hand, participants perceived some OFO officers to profile dark-skinned individuals not fluent in English as unauthorized migrants: "if you are a brown citizen but happen to not speak 'good English,' they get treated like they are trying to cross illegally even though they are American citizens." Other participants reported similar experiences: "my grandparents do not speak any English and oftentimes are questioned whether or not they became actual citizens even though they have all their documentation and are providing it."

\section{Foreign accent/pronunciation}

Seven narratives indicated that knowledge of the English language was not always sufficient to escape OFO officers' suspicions. Some OFO officers also scrutinized the perceived quality, authenticity, and extent of travelers' English skills. Participants perceived border-crossers who spoke with thick Mexican or Latinx accents, struggled with English vocabulary, or used broken English - forming incomplete or very basic English sentences - to be subjected to more rigorous vetting procedures. One participant, for example, reported hearing an OFO officer tell a border-crosser that they "didn't sound American enough." On some occasions, it appears that border-crossers were sent to secondary inspection because of their accents:

The person was of a darker skin complexion with a heavy Mexican accent and was searched top to bottom of all of their belongings. This person was questioned and searched vigorously and after being escorted to a private room [secondary inspection], and authorities discovered that this person was "clear," then the person was released.

Finally, other participants perceived OFO officers to engage in differential treatment based on travelers' "enunciation of phrases in the English language."

\section{Other language-based biases}

Five participants reported receiving differential treatment for language-related reasons, but did not elaborate further on their experiences: "I know the [OFO] officers were doing their job, but I feel that since we are not from America, we look and talk different. So it somehow gives them more of a reason to put us on the spot." Survey responses also indicated that OFO officers engaged in language-related discrimination when they encountered names uncommon in the U.S.: "My first cousin is half Arabian and half Mexican, and we were held at the border for way longer than usual because of his last name." Additionally, some OFO officers who initially established warm rapport with travelers after viewing their U.S. citizenship documents abruptly changed their demeanor after hearing border-crossers speak: "When the [OFO] officers saw my American citizen passport they treat[ed] me with respect, but when they heard me speak they stop[ped] being courteous with me."

\section{Nationality-based discrimination}

\section{Mexican versus American nationalities}

Thirty-seven participants perceived OFO officers to treat travelers differently based on whether they were (or appeared to be) U.S. citizens: "I have been in a travel bus with people from Mexico and I got asked only my name and if I was American while everybody else got questioned and asked for some sort of ID." The above example illustrates how some OFO officers regard individuals who appear American as inherently trustworthy and undeserving of suspicion (to the point of not requiring personal identification). 
In contrast, some OFO officers appeared to express skepticism that individuals with dark skin or prominent Mexican or Latinx features could possibly be from the United States:

When I was literally a child about 9 years old, they [OFO officers] took [me] down [out] of my dad's car and questioned my nationality and where I was born. They allowed my dad to get to me later, [and] I was scared; however, I did not show that because I knew I was telling the truth.

As one participant observed, "People are treated differently based on their skin color and what side of the border they are born [on]." For some participants, being born in the U.S. is enough to allay OFO officers' suspicion - if they also have light skin.

My father and I do not look alike; he's dark skinned, and I am white skinned. Like I said before, I have noticed that he gets treated differently when he crosse[s] the border; he always gets checked, they ask him a lot more questions. He is a big man, so people tend to be afraid of him for some reason, but he is the best father in the world, and it depresses me to know that he is treated differently because of the place he was born. I am Mexican too, just born in the U.S., but I grew up in Mexico, speaking only Spanish for a long time and went to high school in Mexico City. However, others just tend to assume that I am only an American because of the way I look.

One easy (and flawed) way for OFO officers to determine an individual's nationality is to check their vehicle's license plate. According to Julia, an 18-year-old Latina, "When the license plates are Mexican, they [border-crossers] usually get treated very rudely and get inspected more." Emily, a 19year-old Latina, similarly stated, "Cars with license plates from Mexico will be questioned more and almost always sent to get their vehicles checked." One participant observed that "The U.S. Customs [OFO officers] think they can speak to Mexican people in whatever way they want and that is not okay. We are still people!!” Another participant considered OFO officers to treat Mexicans worse under the current presidential administration, saying "They treat Mexicans differently now that Trump is president and threaten to take away their visas."

\section{ID documentation/legal status}

Twenty-three participants perceived OFO officers to discriminate against travelers based on the type of documentation they presented. The types of legal identification OFO officers accepted included, but were not limited to, passports, permanent resident cards (i.e., green cards), and unexpired immigrant visas (U.S. Customs and Border Protection 2007). Lucia, a 21-year-old Latina, observed that "When they [border-crossers] have their green card, they are asked more questions than they usually [are]." Participants without passports reported being harassed by OFO officers: "When I cross with someone without a passport they [OFO officers] start treating us like we're dumb and they ask a lot of questions, which is understandable but at the same time unnecessary." Another participant commented: "me and my family were treated in [a] rude and aggressive manner because we did not have a passport, even though it was for a funeral and too last minute to get a passport." A third participant noted: "Hispanic friends crossing by walking, the darker their skin and having the blue book passport are interviewed longer than my Hispanic light-skinned friends with a card passport." Miguel, a 20-year-old Latino, observed that "People with Mexican visa[s] are treated like second class [sic] citizen[s], or even sometimes abused by the border officers."

\section{Law enforcement behaviors}

\section{Heightened scrutiny/interrogation}

Participants also described OFO officers engaging in common law enforcement practices. Twentytwo participants described OFO officers subjecting "suspicious" border-crossers to intense scrutiny during primary inspection and to outright interrogation in secondary inspection. One participant perceived OFO officers to "talk like they want the person to feel guilty." Another participant witnessed a fellow border-crosser undergo intense questioning from OFO officers who "kept getting in his face" despite answering their inquiries. 
Heightened scrutiny was often the result of ethnic and national biases, but OFO officers also relied on other factors, such as travelers' criminal history. One participant described his uncle being treated differently because he had a prior felony conviction that appeared in the federal database. Another participant described a lengthy exchange with an OFO officer who interrogated him after finding three brand new Apple iPhones lying on his vehicle's backseat. The OFO officer mistakenly thought he was trying to bring the phones into the U.S. without properly declaring them to Customs, but the phones had been purchased in the U.S., and therefore did not need to be declared to Customs upon reentry (the participant was driving back into the U.S. to return the phones). Another example of a situation that draws OFO officers' suspicion is described as follows: "One of the officers asked me directly what address was I using in order to study in the U.S.; she asked because it is known that a lot of students that come from Mexico use the address of their relatives in order to be able to register in a school."

\section{Person/vehicle/possessions searched}

Fifteen participants described OFO officers searching travelers, their personal vehicles, and their belongings. OFO officers are legally able to conduct these searches without establishing reasonable suspicion or obtaining a warrant (19 C.F.R. 162.6). Participants reported experiences ranging from normal searches to more extensive proceedings. One participant, for example, stated, "My parents and I had to get out of our car and be searched." Carlos, a 27-year-old Latino, witnessed multiple searches: "Students, workers, I have seen being mistreated. Border Patrol agents [OFO officers] make them open their lunch and look inside to see what they have." Participant narratives indicated that those subjected to searches often have darker skin or appear visibly Mexican or Latinx: “[OFO officers] looked at every White person's drivers license for a few seconds and gave it back, but to the Mexicans they had to take out their passports, their luggage, and be searched head to toe." Araceli, a 21-year-old Latina, described witnessing a more intense search:

If the [OFO] officer is particularly racist they will make the person basically strip to check them. They did this to my grandfather; they made him lift up his shirt because they were convinced he had something under his shirt. My grandfather complied, but the officer was still rude.

Bob, a 52-year-old White man, recounted a story of an OFO officer searching his car in retaliation for laughing at a joke the OFO officer had found offensive.

\section{Detained/arrested}

Twenty-five participants described witnessing OFO officers detain travelers in secondary inspection or arrest them. On some occasions, ethnic biases appeared to play a role in arrest and detainment decisions: "I got held back to secondary; they patted me down and asked me a bunch of personal questions. Well, my White girlfriend got waved through."

Some participants' experiences suggest that gender may also play a role in OFO officers' detainment decisions:

I have been sent to the side [for secondary inspection] several times; especially being a female I have been questioned. The worst experience I had was this past summer when I traveled to Mexico in a car full of females. I have never been questioned the way I was that time.

Jeff, a 20-year-old White male, witnessed OFO officers arrest his father and take him to secondary inspection after the federal database mistakenly identified him as a convicted felon. Many participants perceived secondary inspection as a long and frustrating process:

There have been several occasions in which my family and I have been taken to a back room [secondary inspection] for additional questioning while crossing the border. The backroom I am referring to has chairs with handcuffs attached, and although I have never personally been handcuffed, I have been made to wait for at least an hour while my documents are checked each time I've been taken there. 
Participants described secondary inspection as a pseudo police interrogation, as OFO officers spoke "loudly and harshly." On some occasions, secondary inspection appeared warranted. One participant, for example, described witnessing OFO officers direct a driver into secondary inspection after finding drugs in his car. On other occasions, however, OFO officers appeared to use secondary inspection without justification:

They [the participant's friends] were kept at the checkpoint for more than 8 hours by the authority or officers even though my friends had all the required documents to enter the U.S.; they had their passports and I-20s. But they were still kept there waiting and the officers checked them physically and also had their phones checked. They were asked if they had any Muslim friends.

\section{Confronting illegal behavior}

Eight participants perceived OFO officers to treat individuals differently because they were engaging in deviant or illegal behavior. One participant, for example, attributed the differential treatment her dad received to the fact that he tried crossing the border using a stolen identity. Another participant witnessed OFO officers treat an individual differently because "the guy that was driving at the moment of the checkpoint was drunk." Other participants also observed OFO officers treat drunken travelers differently. Pedro, a 19-year-old Latino, witnessed OFO officers single an individual out because "the guy had weed on himself and the dogs caught him." Thus, in some situations, OFO officers' differential treatment of border-crossers appears preceded by witnessing travelers engage in deviant or illegal acts.

\section{Militarization}

In two cases, participants commented on OFO officers acting or appearing like military soldiers. U.S. law enforcement units around the country have become increasingly militarized over the past several decades (American Civil Liberties Union 2014), and the U.S.-Mexico border is no exception (Dunn 2001; Heyman 2012; Heyman and Campbell 2012). Brittany, an 18-year-old White female, witnessed "armed forces surrounding them [border-crossers] and taking extra precaution." A second participant described a similar incident: "One time a young Mexican lady was cuffed and about 10 officers surrounded her. Seems pretty extreme for a lady no heavier than 130 pounds." In both incidents, OFO officers appeared to respond to situations with force and weaponry far in excess of what was called for (at least at face value).

These shows of intimidation are consistent with militarization. An American Civil Liberties Union (2014:3) report, for example, noted that the "militarization of policing encourages officers to adopt a 'warrior' mentality and think of the people they are supposed to serve as enemies." Kraska (2007:504) defined militarization as "adopting and applying the central elements of the military model to an organization or particular situation. Police militarization, therefore, is simply the process whereby civilian police increasingly draw from, and pattern themselves around, the military model." Kraska (2007:504) identified four characteristics of militarization: (1) the degree of military equipment and technology used; (2) the degree of military customs and beliefs present in the organization; (3) the degree of military structure adopted by the organization; and (4) the degree of militaristic behaviors organization members engage in, including "highly aggressive and punitive operations such as some zero-tolerance initiatives." This form of militarized intimidation is consistent with the coercive model of compliance and control, which scholars have demonstrated to be a counter-productive way of promoting support for the law and legal system (although some policymakers may come to believe they are tools that law enforcement must use at the border). In contrast, the consensus model stresses the importance of developing a framework and positive interactions with justice officials in order to help build supportive attitudes and values toward the law (Tyler and Trinkner 2018:219). 


\section{Perceived problematic behaviors}

\section{Rude behavior/harassment}

Fifty participants described situations where they perceived OFO officers to have acted in rude or offensive ways, or harassed travelers waiting to cross the border. One participant noted that OFO officers routinely engaged in "microaggressions." Microaggressions are words or behaviors that subtly communicate an individual's inferior social status relative to another, more privileged group (Smith, Allen, and Danley 2007). Another participant recounted "Being yelled at like a soldier in the military because I answered my phone while waiting in line for custom agents." Some perceived harassment incidents took the form of lectures:

While coming back to the U.S. my friends had their passport but I did not, I just had my ID and birth certificate. He [the OFO officer] went [on] about saying how it is because of people like me that make America fail because we are "never prepared." I am making those around me, including my friends, waste time by having him look me up in the [federal database] system. I felt it was rude and irrelevant; as long as I have any source of document it should not be a problem, and he did not have to bring me down for him to work less. It is his job to check for undocumented people, and it is not my position to make his job easier.

Similarly:

I was once, what I consider to this day to have been, irrationally and unprofessionally questioned. I was asked things such as "why are you crossing through this checkpoint if you live on the other side of town? Is that not just a waste of gasoline?" and when I asked to be properly interrogated or to have someone else properly interrogate me, the response was "this is MY interrogation, and this is what I want to know" repeated to me well over six times. I was asked multiple times if there was anything in my vehicle such as drugs or alcohol; I answered no various times, to which I got a chuckle and an "okay, well I hope you're not lying."

Fernando, an 18-year-old Latino, recounted an incident from his childhood:

The story of my mom not yet being a citizen and all three of us siblings being American struck a curiosity in the officers that something was off, so they would ask us and my mom [to] sing the national anthem or [answer] history questions which none of us knew because we were small and not that far along in history or being able to memorize important events.

On some occasions, OFO officers appeared to lash out when their expectations were not met:

There was one time that I was crossing [and] the [OFO] officer asked me a question in Spanish. I answered in English [and] he got mad and demanded me to answer to him in Spanish since I was Mexican.

A second participant similarly reported what he perceived as harassment:

My girlfriend was warned by the U.S. Customs that for not saying she has a bag of chips from Mexico she was going to get her visa taken away when she was asked if she had anything to declare from Mexico. I have crossed various times with potato chips in my hand and they have never told me anything.

At other times, some OFO officers appeared to go out of their way to disparage Mexico:

[OFO officers were] rude and sarcastic with me when ask[ing] why I had gone into [Mexican border city]. [I] let them know that I had only gone for ten minutes to pick up a travel permission slip in order to go visit [another Mexican city]. I handed over the slip to prove that I had the piece of paper and was then told (very rudely) "I didn't ask for the paper, I don't want that thing, that is from Mexico." I felt very disrespected.

Antonio, a 22-year-old Latino, reported witnessing a similar incident: "One of my friends needs to buy contraceptive pills in [Mexican border city] for a treatment, so when she came back to the U.S., one of the officers told her 'It's too bad that you don't want to make babies here in the U.S."

\section{Entitlement/lack of empathy}

Thirteen participants also perceived some OFO officers to act superior to border-crossers, and with impunity: 
I do not have a passport (because there is not a penalty in place if you do not have one) and I am always lectured every single time I cross the border by the agents. I feel it is unnecessary because there is nothing they can do about it, they just want the power trip.

A second participant told the following story: "A lady was assaulted by an [OFO] officer. The officer started yelling to the lady, who was being very respectful, then ripped her off [of] her belongings and cuffed her just to show off." Other participants reported feeling intimidated by OFO officers: "They talk with such power, like if they were better than any of us, and they make people feel bad and nervous so that they can accuse you of whatever they want." As this participant recognized, some OFO officers intentionally intimidate border-crossers, then use travelers' fear and nervousness to justify additional questioning and sending them to secondary inspection. Eduardo recounted one such perceived abuse of power:

My friend who attends [U.S. border city university] with me is a Mexican citizen and lives in [Mexico border city], and he has a student visa that allows him to cross daily to the United States. He once tried to cross on a Saturday and an [OFO] officer did not let him pass because the officer stated that he did not have the correct visa to cross to the United States on a Saturday. He had to go to another bridge, and the officer in the other bridge told him that with his visa he could cross and travel around the U.S. as many times as he needed and wanted. So, maybe the officer in the other bridge decided not to let my friend cross because he felt like it.

Another participant described a perceived abuse of OFO officers' authority: "I had LASIK surgery, which has made my eyes sensitive to light. [A] Border Patrol agent [OFO officer] demanded I remove my sunglasses even after stating it was for medical purposes."

\section{Theft/loss of property}

Three participants described OFO officers stealing or destroying their property: “Around 2011-2012, authorities had us get out of the car for [secondary] inspection and simply took our belongings from the car such as our purses and never gave them back." Another participant described witnessing OFO officers "removing and tearing apart passport cards."

\section{Victimization}

Eleven participants described OFO officers engaging in behaviors that may constitute human rights violations. The United Nations has published a Universal Declaration of Human Rights (2015). Article 5 of this declaration states that "No one shall be subjected to torture or to cruel, inhuman or degrading treatment or punishment" (United Nations 2015:12). The following experiences appear to describe incidents that do not conform to the ideals articulated in Article 5. One participant, for example, described seeing "people get yelled at and even assaulted." Another witnessed a young border-crosser "being forced to chug drugs," which ultimately resulted in the minor's death. ${ }^{9}$ Still another participant observed "a whole team of Customs [officers] jump towards a guy that was being taken out of his vehicle and slammed down." Raul, a 21-year-old Latino, witnessed an OFO officer "stop a car with a family [in it] and start to punch the male adult in the face while their family was watching inside the car." Another participant perceived an OFO officer to have lashed out after his ego was bruised, saying "Around five years ago, an officer threw a Latino student into the floor because he ordered him to stop horsing around and the student answered back to him." Other participants relayed lengthier stories of witnessing and experiencing what they perceived to be victimization:

\footnotetext{
${ }^{9}$ It is unclear whether this participant was referring to having personally witnessed the Cruz Marcelino Velazquez Acevedo incident, or a separate case with similar features. Given that the Cruz incident occurred at the San Ysidro Port of Entry connecting Tijuana, Mexico to San Diego, California (Phillips 2017), the participant may have been describing a separate incident, as all participants were currently attending college in Texas. Alternatively, the participant may have been describing watching the released surveillance footage that showed Cruz drinking the liquid meth, despite the survey question prompts clearly asking participants about their personal experiences and observations "When crossing the U.S.-Mexico border at a border checkpoint."
} 
I have been held in [secondary] inspection for hours despite the fact that I had answered all their [OFO officers'] questions, I had given them my social security number, [and] I had identified myself. They accused my brother of swinging a bat at an officer (we were on our way to play baseball with my father's family as a Christmas tradition we have); however, that was impossible because he was leaning on the bat. They beat my brother, they threatened to beat me as well when I ran to protect him. I ran [to] the bridge to the Mexican side, I spoke to authorities and to my father who was waiting on the other side, but by the time we went back to get my brother, he had been let go.

Amistad, a 25-year-old Latino, also recounted witnessing what he perceived to be an aggressive encounter with OFO officers:

\begin{abstract}
Someone I used to be friends with went to buy some snacks from the sellers near the bridge while I and other friends waited in line and saved his spot. We were headed to a party. When he came back an officer confronted him and accused him of cutting in line and asked him to go with him. Despite explaining that he was with us and we were just saving his spot, the officer continued arguing. Eventually more officer[s] showed up, and then the original officer that had confronted us pulled on my friend's shirt and slammed him to the ground. We were kept back by other officers as they dragged our friend off. After about an hour he was let go, [and] someone that looked like a manager apologized for the incident. We chose to go home instead of going to the party.
\end{abstract}

\title{
Discussion
}

This exploratory study examined the perceptions and experiences of young adults who discussed how border officials treat U.S.-Mexico land port-of-entry travelers. Using a large sample of young adults who had experiences with land port-of-entry border-crossings, we found that participants reported facing perceived discrimination based on the color of their skin, having prominent Mexican or Latinx physical features, being older, and owning possessions that communicated unusual wealth or poverty. NonEnglish speakers, English as a second language (ESL) speakers, and participants with thick Mexican or Latinx accents also reported facing discrimination. Furthermore, participants perceived OFO officers as treating U.S. citizens better than Mexican nationals, in addition to discriminating against persons who provided identification other than a U.S. passport. Participants also described differential treatment when OFO officers engaged in common law enforcement behaviors including intense questioning, interrogation, person and property searches, detainment, and arrest. In a couple instances, OFO officers' engaged in behaviors associated with militarization. This lends some credence to the notion that $\mathrm{CPB}$ has become increasingly militarized over the years (Dunn 2001). Finally, participants perceived some OFO officers to have acted rudely, harassed travelers, displayed entitlement and a lack of empathy, stolen or destroyed personal property, and - in a few instances - violently victimized border-crossers.

These findings are important for several reasons. First, they indicate that some individuals who cross the U.S.-Mexico border at ports of entry witness or experience what they perceive to be discrimination or abuses of power from border officials. Although some may argue that these behaviors could be justified by aspects of the situation unknown to the observer, this does not negate the fact that incidents like these can be jarring to witness out of context. It is worth pointing out that many of the incidents participants described in this study are far less severe than the highprofile episodes recounted in the Texas and New Mexico ACLU reports (ACLU-New Mexico 2015; ACLU-Texas 2016; Saldivar 2017) and other outlets (American Civil Liberties Union 2012; Chavez 2011; Huspek, Martinez, and Jimenez, 1998). Nevertheless, these incidents still reflect an approach to law enforcement that appears more coercive than consensual in nature, and therefore is likely to be a less effective method for fostering compliance and legitimacy (see Tyler 1990).

OFO officers may be the first or only U.S. law enforcement contact to which many port-of-entry travelers are exposed. Thus, border-crossers who witness or experience what they perceive to be discrimination or mistreatment from OFO officers may develop negative views more broadly toward law enforcement and project these views onto local and state police, as well as other government representatives (Seghetti 2016). These procedurally-unjust interactions undermine the legal socialization process, which is critical not only with respect to gaining compliance with the law and legal actors, but also more generally with respect to creating and maintaining effective and productive 
citizen-officer interactions. Consequently, local law enforcement agencies seeking to build strong partnerships with communities may have to work harder to overcome some community members' unfavorable impressions of law enforcement because of their negative encounters with OFO officers. This is particularly true when considering the experiences of communities of color (especially Black American communities; President's Task Force on $21^{\text {st }}$ Century Policing 2015), but also increasingly with respect to migrant communities. The process of navigating ports of entry, with the potential to be subjected to unjust interactions with law enforcement officials, may undermine the legal socialization process for both U.S. citizens and non-citizens alike.

A second finding of importance is that, as a service provider (Cruz and Payan 2017; Yeh 2017), OFO was perceived to be performing less than satisfactory by some respondents. These findings are no doubt partially due to the enormity of the task OFO faces, as well as budgeting and understaffing issues (Heyman 2001; Meyer, Isacson, and Scorpio, 2016). Nevertheless, OFO's challenges extend beyond these concerns. Many U.S.-Mexico ports of entry are overly militarized in the post-9/11 landscape, and, as demonstrated above, some OFO officers display anti-Mexican and anti-MiddleEastern biases. Furthermore, President Trump's incendiary remarks against Mexico have increased ongoing political tensions over whether Mexico is a valuable neighbor and trade partner that helps the U.S. live up to its ideals, or the source of many of the U.S.'s problems (Partlow 2018; Zedillo 2018). The mistreatment and discrimination these participants described witnessing or experiencing at U.S.-Mexico ports of entry is likely the product of all these forces colliding. Just as legitimate fears of terrorism were used to justify authorizing the Transportation Security Administration (TSA) to act with little-to-no oversight at airports post 9/11 (Harrington 2014), the current hyperfocus on unauthorized migrants entering the U.S. threatens to create (or maintain) an environment where racial, ethnic, and national biases can thrive at the border in the name of security.

A third, related finding is that Customs and Border Protection, the largest law enforcement agency in the U.S. (U.S. Customs and Border Protection 2017a), is not immune from similar incidents of racial profiling and discrimination as have plagued smaller state and local police departments in recent years. Highly publicized incidents of systematic discrimination in Ferguson, Missouri (U.S. Department of Justice 2015) and Baltimore, Maryland (The Baltimore Sun 2018), for example, resulted in national and international calls to reform local U.S. law enforcement agencies (Amnesty International 2015; United Nations Human Rights Council 2015). Findings from the current study call to mind the Task Force on 21st Century Policing, which had been established under the previous president Barack Obama. This Task Force recognized that police often treat communities of color unfavorably, and called for law enforcement agencies to work toward increasing their awareness of biases (President's Task Force on 21st Century Policing 2015). Two main points are worth highlighting from the report. First, it recommended that "law enforcement culture should embrace a guardian - rather than a warrior - mindset to build trust and legitimacy both within agencies and with the public" (President's Task Force on 21st Century Policing 2015:1). Second, "if police are to carry out their responsibilities according to established policies, those policies must reflect community values” (p. 2).

Under the former Obama administration, the U.S. began to acknowledge the shortcomings of law enforcement in their interactions with communities of color. This acknowledgment was accompanied by calls for increased accountability and oversight of police. Unfortunately, the need for similar calls of accountability and oversight at U.S.-Mexico ports of entry has been largely overlooked by scholars (although see Saldivar 2017). Nevertheless, findings from the present study suggest that some aspects of the OFO bear further investigation. Although it is too soon to tell, future research may reveal that OFO culture requires reshaping and stands to benefit from implementing elements of other domestic law enforcement reform efforts. OFO officers are often one of the first formal contacts border-crossers have with the U.S., and as such serve an important diplomatic function in addition to their role as law enforcement officers. Consequently, OFO culture should discourage the warrior mindset and instead train officers to have a diplomat-oriented mindset in keeping with the recommendations from the Task Force on 21st Century Policing, and with the legal socialization literature more generally (e.g., Tyler and Trinkner 2018). This training should also emphasize the importance for OFO officers to demonstrate 
and uphold professed U.S. values like equality, fairness, justice, and respect for human rights (ACLUTexas 2016; Revitalize Not Militarize n.d.). OFO officers who embrace these U.S. ideals will ensure they are engaging in behaviors and practices that "reflect [the] community values" of U.S.-Mexico border communities (President's Task Force on 21st Century Policing 2015:2).

The fourth and final finding worth highlighting is that of the 972 individuals who had crossed the U.S.-Mexico border at a port of entry at least once, only 191 elected to provide a response to the openended question prompts (19.7\%). This raises questions regarding self-selection and self-report methodologies, which do not necessarily capture the behavior of OFO officers, but instead the perceptions of their behavior. To the first point, it is possible that non-responders had different experiences than those who chose to respond. This may be the case, as individuals who had especially negative experiences likely welcomed an outlet to describe their experiences and draw attention to what they perceived to be problematic treatment. In contrast, individuals satisfied with their treatment at U.S.-Mexico ports of entry may not have seen a need to provide feedback intended to improve a service they already considered satisfactory. Thus, the narratives of perceived discrimination and mistreatment that participants provided belong to a proportionally small subset of all participants in this study who had crossed the U.S.-Mexico border at a land port of entry at least once. As such, these narratives may not be generalizable to the overall population of U.S.-Mexico port-of-entry travelers.

Nevertheless, qualitative approaches facilitate the extensive examination of the topic under discussion (Gerbert et al. 1999) - an aspect of research that is arguably as important as generalizability. Tewksbury (2009:55) suggests that qualitative strategies help to "paint a picture of wholeness" by helping explain the numerous factors that shape individual experiences. The ability to gain an in-depth understanding about the phenomenon of interest in the present study, therefore, helps to minimize some of the potential limitations regarding generalizability (Tewksbury 2009). To the second point, as with most qualitative techniques, limitations exist when research relies on self-reported data. For example, participants may censor their responses in order to provide what they consider more socially acceptable answers. They may also provide misleading responses due to poor memory recall, or not be as knowledgeable about the topic under study as the researcher assumes they are (see Stone et al. 1999 for a discussion of the limitations of self-report data). Furthermore, the survey-based nature of the present study did not permit a more in-depth data collection based on experiences and perceptions that may be better attained through focus groups or interviews, though these methods face limitations as well.

It is also worth noting that a review of participants' responses indicate that some participants may have perceived the four questions asked in this study to be fundamentally similar and asking the same question four different ways, resulting in later questions being left blank. For example, one participant wrote "explained" for a later question, suggesting they had already answered this question with their response to the first question. Another participant wrote "AGAIN..." to a later question before reiterating their response to the first question, indicating they felt the later question was repetitive. Similarly, a participant began their response to a later question with, "Like I said..." Yet another participant began responses to two separate questions after the first question with "like I said earlier..." and "also like I explained earlier...," respectively. An additional participant took the same approach, beginning responses to two questions after the first with "As previously stated..." and "already stated..." Other responses included "The same as previous question," "Please see previous questions," "same as before," "see previous example," and "I just gave my explanation in the previous question." Some participants also copy-and-pasted the same response to all four questions, and others told the same story in slightly different ways in response to the four questions. Thus, while the questions were designed to capture different themes and experiences, future research efforts should expand on the range and phrasing of questions presented to participants.

In closing, the present study emphasized the importance for researchers to shed light on travelers' border-crossing experiences at U.S.-Mexico ports of entry by demonstrating that a subset of travelers experience what they perceive to be discrimination and mistreatment from OFO officers. To date, researchers have largely focused on unauthorized migrants' experiences in the U.S. (e.g., Becerra et al. 2017; Garcini et al. 2017). This focus is understandable given that migrants' unauthorized status 
in the U.S. renders them uniquely vulnerable to victimization (Comino, Mastrobuoni, and Nicolo, 2016). The majority of individuals who enter the U.S., however, do so through U.S.-Mexico land ports of entry rather than clandestine crossings between ports. The sheer volume of border traffic entering the U.S. through U.S.-Mexico ports of entry - 42.3 million pedestrians and 143.6 million personal vehicle passengers in 2017 (Bureau of Transportation Statistics n.d.) - makes these individuals (both migrants and U.S. citizens) a compelling population for study. Given the antiMexican and xenophobic sentiments emanating from the current President's administration, there is a danger of repeating previous abuses of power that have been well-chronicled in the literature and media. One way to improve accountability from the OFO is for scholars to shed a light on how everyday travelers are treated when they cross the U.S.-Mexico border.

We conclude by encouraging social scientists to examine the broader picture of law enforcement operations at the southern border and across different races and ethnicities. This picture cannot be complete without accounting for border-crossing experiences and policing practices at U.S.-Mexico ports of entry. Information from this study and future work should be used to form a requisite knowledge base geared toward informing policy and practice at border-crossings in order to ensure procedurally-just interactions with the law, which research has identified as an effective method for gaining compliance and improving legitimacy (Tyler 1990). This is an issue that spans many different types of marginalized communities, and in particular - as shown in our study - Latinx communities that are disproportionately affected by anti-Mexican stereotypes. Stereotypes about the criminal or illegal nature of migrants and Latinxs have existed for quite some time, despite a lack of evidence that these communities are more likely to offend or bring unique problems and social ills with them to the United States (see e.g., Bersani et al. 2014, 2018; Ousey and Kubrin 2018). One of the major challenges the United States faces in the twenty-first century is how to reshape these popular misperceptions to fit the facts. This challenge only grows in importance as the U.S. experiences continued increases in the Latinx and foreign-born populations that appear poised to transform the U.S. into a majority-minority country by the year 2044 (Colby and Ortman 2015).

\section{Notes on contributors}

Alexander H. Updegrove is a Doctoral Research Assistant in the Department of Criminal Justice and Criminology at Sam Houston State University. His research interests include race and crime, immigration, and victimology. His recent works have appeared in Justice Quarterly, Crime \& Delinquency, and the International Journal of Offender Therapy and Comparative Criminology. He will be starting a position as an Assistant Professor in the Department of Social Sciences at Texas A\&M International University in Fall 2019.

Joshua T. Shadwick is a doctoral student in the Department of Criminal Justice and Criminology at Sam Houston State University. His research focuses on the justice system's response to public health and safety-related problems, with a specific focus on police responses to these social issues.

Eryn Nicole O'Neal (Ph.D., Arizona State University School of Criminology \& Criminal Justice) is an assistant professor in the Department of Criminal Justice and Criminology at Sam Houston State University. Her research has appeared in a variety of scholarly journals, including Justice Quarterly, Violence Against Women, Feminist Criminology, Women \& Criminal Justice, and Journal of Interpersonal Violence. She recently received both the American Society of Criminology Division on Women and Crime New Scholar Award (2017) and the Division of Victimology Faculty Researcher of the Year Award (2018). In 2018, she received the Academy of Criminal Justice Sciences (ACJS) William L. Simon/Routledge Outstanding Paper Award (first author Brittany E. Hayes).

Alex R. Piquero is Ashbel Smith Professor of Criminology and Associate Dean for Graduate Programs in the School of Economic, Political and Policy Sciences at the University of Texas at Dallas and an Adjunct Professor in the Key Centre for Ethics, Law and Governance at Griffith University. His research interests include criminal careers, criminological theory, and quantitative research methods. He currently serves as editor of Justice Evaluation Journal. He has received several research, teaching, and service awards and is fellow of both the American Society of Criminology and the Academy of Criminal Justice Sciences. In 2014, he received The University of Texas System Regents' Outstanding Teaching Award and in 2018 he was named to The University of Texas System Academy of Distinguished Teachers. 


\section{References}

ACLU-New Mexico. 2015, May. “Guilty until Proven Innocent: Living in New Mexico's 100-Mile Zone.” Retrieved January 24, 2018 (https://www.aclu-nm.org/sites/default/files/wysiwyg/aclu-nm_guiltyuntilproveninnocentfinal5_ 15_2015_2.pdf).

ACLU-Texas. 2016, May 17. “ACLU Urges Investigation into Abusive Treatment at CBP Ports of Entry.” Retrieved January 24, 2018 (https://www.aclutx.org/en/press-releases/aclu-urges-investigation-abusive-treatment-cbp-ports-entry).

American Civil Liberties Union. 2012, May 9. "Re: Complain and Request for Investigation of Abuse of Power, Excessive Force, Coercion, and Unlawful Confiscation of Property by Customs and Border Protection at Ports of Entry along the U.S.-Mexico Border.” Retrieved January 24, 2018 (https://www.aclu.org/files/assets/aclu_2012_cbp_ abuse_complaint_2.pdf).

American Civil Liberties Union. 2014. “War Comes Home: The Excessive Militarization of American Policing.” Retrieved February 20, 2018 (https://www.aclu.org/sites/default/files/assets/jus14-warcomeshome-report-web-rel1.pdf).

Amnesty International. 2012. "In Hostile Terrain: Human Rights Violations in Immigration Enforcement in the U.S. Southwest.” Retrieved January 29, 2018 (https://www.amnestyusa.org/files/ai_inhostileterrain_final031412.pdf).

Amnesty International. 2015. "Deadly Force: Police Use of Lethal Force in the United States." Retrieved February 12, 2018 (https://www.amnestyusa.org/files/aiusa_deadlyforcereportjune2015.pdf).

Becerra, David, M., Alex Wagaman, David Androff, Jill Messing, and Jason Castillo. 2017. "Policing Immigrants: Fear of Deportations and Perceptions of Law Enforcement and Criminal Justice." Journal of Social Work 17 (6):715-31. doi:10.1177/1468017316651995.

Bedard, Paul. 2017, July 18. "ICE Chief: 80\% Jump in Illegal Targets, Readies National 'Sanctuary' Crackdown.” Washington Examiner. Retrieved February 12, 2018 (http://www.washingtonexaminer.com/ice-chief-80-jump-inillegal-targets-readies-national-sanctuary-crackdown/article/2629001).

Bernard, H. R. 2000. Social Research Methods. Thousand Oaks, CA: Sage.

Bersani, Bianca E., Adam D. Fine, Alex R. Piquero, Laurence Steinberg, Paul J. Frick, and Elizabeth Cauffman. 2018. "Investigating the Offending Histories of Undocumented Immigrations." Migration Letters 15 (2):147-66. doi: $10.33182 / \mathrm{ml} . v 15 \mathrm{i} 2.366$

Bersani, Bianca E., Thomas A. Loughran, and Alex R. Piquero. 2014. "Comparing Patterns and Predictors of Immigrant Offending among a Sample of Adjudicated Youth.” Journal of Youth \& Adolescense 43:1914-33. doi:10.1007/s10964-013-0045-z.

Brill, Steven. 2016, September. “Is America Any Safer?” The Atlantic. Retrieved July 10, 2018 (https://www.theatlantic. com/magazine/archive/2016/09/are-we-any-safer/492761/).

Bureau of Transportation Statistics. n.d. "Border Crossing/Entry Data." Retrieved February 12, 2018 (https://www.bts. gov/content/border-crossingentry-data).

Bustillos v. El Paso County Hospital District. 2016. 226 F.Supp.3d 778.

Cervantes v. United States of America. 2016, June 8. case 4:16-cv-00334-CKJ. Retrieved January 27, 2018 (https:// assets.documentcloud.org/documents/2863177/Cervantes.pdf).

Chacón, Jennifer M. and Susan Bibler Coutin. 2018. "Racialization through Enforcement." Pp. 159-75 in Race, Criminal Justice, and Migration Control: Enforcing the Boundaries of Belonging, edited by Mary Bosworth, Alpa Parmar, and Yolanda Vázquez. New York, NY: Oxford University Press.

Charmaz, K. 2014. Constructing Grounded Theory. 2nd ed. Thousand Oaks, CA: Sage.

Chavez, Leo R. 2008. The Latino Threat: Constructing Immigrants, Citizens, and the Nation. Redwood City, CA: Stanford University Press.

Chavez, Sergio. 2011. "Navigating the U.S.-Mexico Border: The Crossing Strategies of Undocumented Workers in Tijuana, Mexico." Ethnic and Racial Studies 34 (8):1320-37. doi:10.1080/01419870.2010.547586.

Clarke, A. (2005). Situational analysis: Grounded theory after the postmodern turn.Thousand Oaks, CA: Sage.

Coates, Ta-Nehisi. 2015. Between the World and Me. New York, NY: Spiegel \& Grau.

Colby, Sandra L. and Jennifer M. Ortman. 2015, March. "Projections of the Size and Composition of the U.S. Population: 2014 to 2060.” United States Census Bureau. Retrieved March 28, 2018 (https://www.census.gov/ content/dam/Census/library/publications/2015/demo/p25-1143.pdf).

Collins, M., Fritze, J., \& Jackson, D. (2019, January 12). Government shutdown sets record as longest in U.S. history. When will it finally end? USA Today. Retrieved January 14, 2019, from https://www.usatoday.com/story/news/ politics/2019/01/12/government-shutdown-standoff-now-longest-ever-when-end/2546949002/

Comino, Stefano, Giovanni Mastrobuoni, and Antonio Nicolo. 2016. "Silence of the Innocents: Illegal Immigrants' Underreporting of Crime and Their Victimization.” IZA Discussion Paper No. 10306, 1-49. Retrieved February 21, 2018 (https://papers.ssrn.com/sol3/papers.cfm?abstract_id=2861091).

Creswell, J. 1998. Qualitative Inquiry and Research Design: Choosing among Five Traditions. Thousand Oaks, $C$ A. Sage.

Cruz, Pamela L. and Tony Payan. 2017. "Customs and Border Protection Abuses at Ports of Entry along the U.S.-Mexico Border.” Baker Institute for Public Policy. Retrieved January 24, 2018 (https://www.bakerinstitute. org/media/files/files/fa432332/BI-Brief-011217-MEX_BorderAbuses.pdf). 
Culosi, Salvatore J, Sr. 2014, December 24. "Letters to the Editor: Justice for John Greer's Death." The Washington Post. Retrieved July 10, 2018 (https://www.washingtonpost.com/opinions/justice-for-john-geers-death/2014/12/24/ 912fa192-8a1d-11e4-ace9-47de1af4c3eb_story.html?utm_term=.87f3d413f2a9).

De Leon, Jason, Cameron Gokee, and Ashley Schubert. 2015. “'By the Time I Get to Arizona': Citizenship, Materiality, and Contested Identities along the U.S.-Mexico Border.” Anthropological Quarterly 88 (2):445-79. doi:10.1353/ anq.2015.0022.

Dear, Michael. 2013. Why Walls Won't Work: Repairing the US-Mexico Divide. New York, NY: Oxford University Press.

Department of Homeland Security. 2016, October 17. "Statement by Secretary Johnson on Southwest Border Security." Retrieved February 25, 2018 (https://www.dhs.gov/news/2016/10/17/statement-secretary-johnson-southwest-border -security).

Domonoske, Camila and Richard Gonzales. 2018, June 19. "What We Know: Family Separation and 'Zero Tolerance' at the Border." National Public Radio. Retrieved July 10, 2018 (https://www.npr.org/2018/06/19/621065383/what-we -know-family-separation-and-zero-tolerance-at-the-border).

Dunn, Timothy J. 2001. "Border Militarization via Drug and Immigration Enforcement: Human Rights Implications." Social Justice 28 (2):7-30.

Eberhardt, Jennifer L., Paul G. Davies, Valerie J. Purdie-Vaughns, and Sheri Lynn Johnson. 2006. "Looking Deathworthy: Perceived Stereotypicality of Black Defendants Predicts Capital-Sentencing Outcomes." Psychological Science 17:383-86. doi:10.1111/j.1467-9280.2006.01716.x.

Fagan, Jeffrey and Alex R. Piquero. 2007. "Rational Choice and Developmental Influences on Recidivism among Adolescent Felony Offenders.” Journal of Empirical Legal Studies 4:715-48. doi:10.1111/j.1740-1461.2007.00105.x.

Finnegan, Michael. 2016, June 3. “It's Going to Be a Big, Fat, Beautiful Wall!': Trump's Words Makes His California Climb an Even Steeper Trek.” Los Angeles Times. Retrieved February 7, 2018 (http://www.latimes.com/politics/la-na -pol-trump-california-campaign-20160602-snap-story.html).

Gambino, Lauren. 2018, January 6. "Trump Claims Mexico Will Pay for Wall Day after Seeking $\$ 18 \mathrm{bn}$ from Congress.” The Guardian. Retrieved February 7, 2018 (https://www.theguardian.com/us-news/2018/jan/06/donaldtrump-mexico-border-wall-funding).

Garcini, Luz M., Juan M. Pena, Christopher P. Thania Galvan, Vanessa Malcarne Fagundes, and Elizabeth A. Klonoff. 2017. "Mental Disorders among Undocumented Mexican Immigrants in High-risk Neighborhoods: Prevalence, Comorbidity, and Vulnerabilities." Journal of Consulting and Clinical Psychology 85 (10):927-36. doi: 10.1037/ccp0000237.

Gerbert, B., P. Abercrombie, N. Caspers, C. Love, and A. Bronstone. 1999. "How Health Care Providers Help Battered Women: The Survivor's Perspective.” Women \& Health 29 (3):115-135. doi:10.1300/J013v29n03_08.

Glaude, Eddie S, Jr. 2016. Democracy in Black: How Race Still Enslaves The American Soul. New York, NY: Crown.

Glaser, B. G. \& Strauss, A. L. 1967. The discovery of grounded theory. Chicago, IL: Aldine.

Harrington, Jason Edward. 2014, January 30. "Dear America, I Saw You Naked: And Yes, We Were Laughing. Confessions of an Ex-TSA Agent.” Politico Magazine. Retrieved July 10, 2018 (https://www.politico.com/magazine/ story/2014/01/tsa-screener-confession-102912).

Heyman, Josiah McC. 2001. "U.S. Ports of Entry on the Mexican Border." Journal of the Southwest 43 (4):681-700.

Heyman, Josiah McC. 2009. "Trust, Privilege, and Discretion in the Governance of the U.S. Borderlands with Mexico." Canadian Journal of Law and Society 24 (3):367-90. doi:10.1017/S0829320100010085.

Heyman, Josiah. 2012. "Capitalism and U.S. Policy at the Mexican Border." Dialectical Anthropology 36 (3-4):263-77. doi:10.1007/s10624-012-9274-x

Heyman, Josiah. 2013. "A Voice of the U.S. Southwestern Border: The 2012 'We the Border: Envisioning A Narrative for Our Future' Conference.” Journal on Migration and Human Security 1 (2):60-75. doi:10.1177/ 233150241300100201

Heyman, Josiah and Howard Campbell. 2012. "The Militarization of the United States-Mexico Border Region.” REU, Sorocaba, SP 38 (1):75-94.

Huspek, Michael, Roberto Martinez, and Leticia Jimenez. 1998. "Violations of Human and Civil Rights on the U.S.-Mexico Border, 1995 to 1997: A Report.” Social Justice 25 (2):110-30.

Integrated Postsecondary Education Data System. n.d. "Find Your College.” Retrieved March 28, 2018 (https://nces.ed. gov/ipeds/find-your-college).

Jackman, Tom. 2011, January 18. "Fairfax Finalizes \$2 Million Settlement with Culosi Family in 2006 Police Shooting." The Washington Post. Retrieved July 10, 2018 (http://www.washingtonpost.com/wp-dyn/content/story/2011/01/18/ ST2011011805168.html).

Jane Doe v. The El Paso County Hospital District, 2013 WL 6989644. 2013, December 18. Retrieved January 26, 2018 (https://www.aclutx.org/sites/default/files/field_documents/doevelpasohospdist-filed1.pdf).

Kraska, Peter B. 2007. "Militarization and Policing-Its Relevance to 21st Century Police." Policing: A Journal of Policy and Practice 1 (4):501-13. doi:10.1093/police/pam065.

Kraska, Peter B. and Victor E. Kappeler. 1997. "Militarizing American Police: The Rise and Normalization of Paramilitary Units.” Social Problems 44 (1):1-18. doi:10.2307/3096870. 
Lee, Hee and Ye. Michelle 2015, July 8. "Donald Trump's False Comments Connecting Mexican Immigrants and Crime." The Washington Post. Retrieved January 24, 2018 (https://www.washingtonpost.com/news/fact-checker /wp/2015/07/08/donald-trumps-false-comments-connecting-mexican-immigrants-and-crime/?utm_term=. 0af6ecdba22f).

Levario, Miguel Antonio. 2012. Militarizing the Border: When Mexicans Became the Enemy. College Station: Texas A\&M University Press.

Mayring, Philipp. 2014. "Qualtitative Content Analysis: Theoretical Foundation, Basic Procedures and Software Solution.” Social Science Open Access Repository, 1-143. Retrieved October 22, 2017 (http://nbn-resolving.de/urn: nbn:de:0168-ssoar-395173).

McEwan, Jenny. 2003. The Verdict of the Court: Passing Judgment in Law and Psychology. Oxford, UK: Hart.

Meyer, Maureen, Adam Isacson, and Carolyn Scorpio. 2016, October. "Not a National Security Crisis: The U.S.-Mexico Border and Humanitarian Concerns, Seen from El Paso." The Washington Office on Latin America. Retrieved January 26, 2018 (https://www.wola.org/wp-content/uploads/2016/10/WOLA_NoNationalSecurityCrisis_ October2016.pdf).

Militarize, Revitalize Not. n.d. “Dignity Crossing.” Retrieved January 24, 2018 (http://www.revitalizenotmilitarize.org/ dignity-crossing/).

Morse, J. M. 1994. Designing funded qualitative research. In N. K. Denzin \& Y. S. Lincoln(Eds.), Handbook of qualitative research (2nd ed.). (pp. 220-235). Thousand Oaks, CA:Sage.

Morse, J. M., M. Barrett, M. Mayan, K. Olson, and J. Spiers. 2002. "Verification Strategies for Establishing Reliability and Validity in Qualitative Research." International Journal of Qualitative Methods 1:13-22. doi:10.1177/ 160940690200100202.

Ortiz, Laura Velasco and Oscar F. Contreras. 2011. Mexican Voices of the Border Region: Mexicans and Mexican Americans Speak about Living along the Wall. Philadelphia, PA: Temple University Press.

Ortiz, Vilma and Edward Telles. 2012. "Racial Identity and Racial Treatment of Mexican Americans." Race and Social Problems 4 (1):41-56. doi:10.1007/s12552-012-9064-8

Ousey, Graham C. and Charis E. Kubrin. 2018. "Immigration and Crime: Assessing a Contentious Issue.” Annual Review of Criminaology 1:63-84. doi: 10.1146/annurev-criminol-032317-092026

Partlow, Joshua. 2018, May 10. "In Mexico, Frustration with Trump Grows as Relations Reach a 'Defining Moment'. The Washington Post. Retrieved July 12, 2018 (https://www.washingtonpost.com/world/the_americas/in-mexicofrustration-with-trump-grows-as-relations-reach-a-defining-moment/2018/05/09/57450340-41db-11e8-b2dcb0a403e4720a_story.html?utm_term=.682d99e01693).

Phillips, Kristine. 2017, July 29. "Video Shows U.S. Border Officers Telling Mexican Teen to Drink the Liquid Meth that Killed Him.” The Washington Post. Retrieved January 26, 2018 (https://www.washingtonpost.com/news/postnation/wp/2017/07/29/video-shows-u-s-border-officers-telling-mexican-teen-to-drink-the-liquid-meth-that-killed$\mathrm{him} /$ ?utm_term=.f963d707c657).

Piquero, Alex R., Jeffrey Fagan, Edward P. Muvley, Laurence Steinberg, and Candice Odgers. 2005. "Developmental Trajectories of Legal Socialization among Serious Adolescent Offenders." Journal of Criminal Law \& Criminology 96:267-98.

President's Task Force on 21st Century Policing (2015, May). Final report of the President's Task Force on 21st Century Policing. Washington, DC: Office of Community Oriented Policing Services. Retrieved January 28, 2019, from. https:// cops.usdoj.gov/pdf/taskforce/taskforce_finalreport.pdf

Robbins, Liz and Caitlin Dickerson. 2018, January 23. "What Is DACA? Who are the Dreamers? Here are Some Answers." The New York Times. Retrieved February 8, 2018 (https://www.nytimes.com/2018/01/23/us/dacadreamers-shutdown.html).

Rosas, Gilberto. 2006. “The Thickening Borderlands: Diffused Exceptionality and 'Immigrant' Social Struggles during the 'War on Terror.'." Cultural Dynamics 18 (3):335-49. doi:10.1177/0921374006071618

Sabo, Samantha, Susan Shaw, Maia Ingram, Nicolette Teufel-Shone, Scott Carvajal, Jill Guernsey de Zapien, Cecilia Rosales, Flor Redondo, Gina Garcia, and Raquel Rubio-Goldsmith. 2014. "Everyday Violence, Structural Racism and Mistreatment at the U.S.-Mexico Border." Social Science \& Medicine 109 66-74. doi:10.1016/j. socscimed.2014.02.005.

Saldivar, Edgar. 2017, December 7. "Customs and Border Protection Is Out of Control." Texas ACLU. Retrieved January 24, 2018 (https://www.aclutx.org/en/news/customs-and-border-patrol-out-control).

Sarabia, Heidy. 2015. "Global South Cosmopolitans: The Opening and Closing of the USA-Mexico Border for Mexican Tourists." Ethnic and Racial Studies 38 (2):227-42. doi:10.1080/01419870.2014.887741

Seghetti, Lia. 2016, January 26. "Border Security: Immigration Inspections at Ports of Entry." Congressional Research Service. Retrieved January 27, 2018 (https://fas.org/sgp/crs/homesec/R43356.pdf).

Smith, William A., Walter R. Allen, and Lynette L. Danley. 2007. “'Assume the Position...You Fit the Description': Psychosocial Experiences and Racial Battle Fatigue among African American Male College Students.” American Behavioral Scientist 51 (4):551-78. doi:10.1177/0002764207307742.

Stone, Arthur A., Christine A. Bachrach, Jared B. Jobe, Howard S. Kurtzman, and Virginia S. Cain. 1999. The Science of Self-Report: Implications for Research and Practice. Abingdon, UK: Taylor \& Francis. 
The Baltimore Sun. 2018, February 12. "Force Corruption Trial, Updated with Day 8." The Baltimore Sun. Retrieved February 12, 2018 (http://www.baltimoresun.com/news/maryland/crime/bs-md-ci-gun-trace-task-force-gttftestimony-highlights-20180126-story.html).

Tewksburry, Richard. 2009. "Qualitative versus Quantitative Methods: Understanding Why Qualitative Methods are Superior for Criminology and Criminal Justice.” Journal of Theoretical and Philosophical Criminology 1:38-58.

The Pew Charitable Trusts. 2015, February 6. "Immigration Enforcement along U.S. Borders and at Ports of Entry: Federal, State, and Local Efforts.” Retrieved January 28, 2018 (http://www.pewtrusts.org/ /media/assets/2015/02/ borderenforcement_brief_web.pdf).

Tyler, Tom R. 1990. Why People Obey the Law. New Haven, CT: Yale University Press.

Tyler, Tom R. 2003. "Procedural Justice, Legitimacy, and the Effective Rule of Law." Pp. 283-357 in Crime and Justice: A Review of Research 30, edited by Michael Tonry. Chicago, IL: University of Chicago Press.

Tyler, Tom R., and Rick Trinkner. 2018. Why Children Follow Rules: Legal Socialization and The Development Of Legitimacy. Oxford, UK: Oxford University Press.

Updegrove, Alexander H. 2018. Acculturation and capital punishment: The effect of Mexico versus United States cultural orientations on public support for the death penalty. International Journal of Offender Therapy and Comparative Criminology, 1-22. doi:10.1177/0306624X18815993

U.S. Customs and Border Protection. 2007. "Welcome to the United States: A Guide for International Visitors." Retrieved July 10, 2018 (https://www.cbp.gov/sites/default/files/documents/welcometotheus.pdf).

U.S. Customs and Border Protection. 2017a, December. "Snapshot: A Summary of CBP Facts and Figures." Retrieved January 28, 2018 (https://www.cbp.gov/sites/default/files/assets/documents/2017-Dec/cbp-snapshot-20171208.pdf).

U.S. Customs and Border Protection. 2017b, November 8. "CPB through the Years." Retrieved January 24, 2018 (https://www.cbp.gov/about/history).

U.S. Customs and Border Protection. 2017c. "Performance and Accountability Report: Fiscal Year 2016." Retrieved January 24, 2018 (https://www.cbp.gov/sites/default/files/assets/documents/2017-Mar/FY-2016-CBP-PAR-508C.pdf).

U.S. Customs and Border Protection. 2017d, April 26. "Executive Assistant Commissioners' Offices." Retrieved January 24, 2018 (https://www.cbp.gov/about/leadership-organization/executive-assistant-commissioners-offices).

United Nations. 2015. “Universal Declaration of Human Rights.” Retrieved March 26, 2018 (http://www.un.org/en/ udhrbook/pdf/udhr_booklet_en_web.pdf).

United Nations Human Rights Council. 2015, May 21. "Draft Report of the Working Group on the Universal Periodic Review: United States of America.” Retrieved February 12, 2018 (https://www.upr-info.org/sites/default/files/docu ment/united_states/session_22_-_may_2015/a_hrc_wg.6_22_1.10.pdf).

United States Department of Justice Civil Rights Division. 2015, March 4. "Investigation of the Ferguson Police Department." Retrieved February 12, 2018 (https://www.justice.gov/sites/default/files/opa/press-releases/attach ments/2015/03/04/ferguson_police_department_report.pdf).

Yeh, Rihan. 2017. "On the Possibility of Imagining an Open Border." Political and Legal Anthropology Review 40 (2):295-310. doi:10.1111/plar.12221.

Zedillo, Ernesto. 2018, May 7. "Former Mexican President: Mexico and Canada, Don't Cave to Trump." The Washington Post. Retrieved July 12, 2018 (https://www.washingtonpost.com/news/theworldpost/wp/2018/05/07/ nafta/?utm_term $=.9940 \mathrm{cda} 8535 \mathrm{c})$. 


\title{
"If They Notice I'm Mexican": Narratives of Perceived Discrimination from Individuals Who Crossed the U.S.-Mexico Border at Ports of Entry
}

\author{
Alexander H. Updegrove, Joshua T. Shadwick, Eryn Nicole O’Neal \& Alex R. \\ Piquero
}

To cite this article: Alexander H. Updegrove, Joshua T. Shadwick, Eryn Nicole O'Neal \& Alex R. Piquero (2019): "If They Notice I'm Mexican": Narratives of Perceived Discrimination from Individuals Who Crossed the U.S.-Mexico Border at Ports of Entry, Deviant Behavior, DOI: 10.1080/01639625.2019.1572068

To link to this article: https://doi.org/10.1080/01639625.2019.1572068

曲 Published online: 09 Feb 2019.

Submit your article to this journal 주

Џلll Article views: 388

View Crossmark data ¿ 